Abstracta Iranica Abstracta Iranica

Revue bibliographique pour le domaine irano-aryen

Volume 24 | 2003

Comptes rendus des publications de 2001

Pax to sindgay, nawezuna. Sapi's Center for Pushto Research and Developpement, Peshawar, 2000, 794 p. [Petit dictionnaire pachto : néologismes]

Daniel Septfonds

(2) OpenEdition

Journals

Édition électronique

URL : http://journals.openedition.org/abstractairanica/34225

ISSN : 1961-960X

Éditeur:

CNRS (UMR 7528 Mondes iraniens et indiens), Éditions de l'IFRI

Édition imprimée

Date de publication : 15 mai 2003

ISSN : 0240-8910

Référence électronique

Daniel Septfonds, "Pəx ${ }^{\circ}$ to sindgay, nawezuna. Sapi's Center for Pushto Research and Developpement, Peshawar, 2000, 794 p. [Petit dictionnaire pachto : néologismes] », Abstracta Iranica [En ligne], Volume 24 | 2003, document 28, mis en ligne le 05 janvier 2010, consulté le 25 septembre 2020. URL : http:// journals.openedition.org/abstractairanica/34225

Ce document a été généré automatiquement le 25 septembre 2020

Tous droits réservés 


\title{
Pax to sindgay, nawezuna. Sapi's Center for Pushto Research and Developpement, Peshawar, 2000, 794 p. [Petit dictionnaire pachto : néologismes]
}

\author{
Daniel Septfonds
}

1 Zyār est l'un des précurseurs de l'enrichissement du vocabulaire pashto par la création de néologismes. Dans ce dictionnaire de quelque 7000 entrées, il donne l'essentiel des mots qui ont été créés soit par lui-même directement, soit sous sa direction. Chaque mot en graphie pashto est suivi de sa transcription phonétique puis de ses équivalents courants qui sont généralement des mots empruntés.

2 La transcription est généralement précise mais, sans doute pour des raisons techniques, la voyelle centrale « $a$ » est systématiquement remplacée par « a ». Par ailleurs, on est parfois surpris de retrouver comme néologismes des mots du pashto courant par ex. kac (berg), luțmār (pilleur), sarkār (gouvernement), wagaray (personne) etc.

De nombreux auteurs pachtounes contemporains font un usage intensif des néologismes en remplacement des mots courants mais empruntés au persan et l'arabe. Cet ouvrage rendra plus accessible la lecture de ces auteurs.

\section{INDEX}

Thèmes : 2.2. Langues vivantes et dialectes 
AUTEURS

DANIEL SEPTFONDS

INaLCO - Paris 